\title{
PEMBERIAN PROBIOTIK PADA PENGOLAHAN LIMBAH UDANG YANG DIMASAK DENGAN TEKANAN TINGGI TERHADAP KANDUNGAN PROTEIN KASAR DAN SERAT KASAR
}

\section{GIVING PROBIOTIC AT PRAWN WASTE PROCESSING WITH HIGH PRESSURE COOKED FOR CRUDE PROTEIN AND CRUDE FIBRE CONTENT}

\author{
Agustono $^{1}$, Ika Agustin Handyani ${ }^{1}$, dan Mirni Lamid ${ }^{2}$ \\ ${ }^{1}$ Fakultas Perikanan dan Kelautan Universitas Airlangga \\ Kampus C Mulyorejo - Surabaya, 60115 Telp. 031-5911451 \\ ${ }^{2}$ Fakultas Kedokteran Hewan Universitas Airlangga \\ Kampus C Mulyorejo - Surabaya, 60115 Telp. 031-5992785
}

\begin{abstract}
Feed is one of the factors determines the success of a fish farm. Feed-quality feed stuffs that require high quality also, which still rely on imports, especially fish meal and soybean oilcake. Effort to reduce dependence on import of feed stuff is searching for alternative feed stuffs that the quality is quite good, cheap, easily obtained and can reduce cost of production. One of the feed stuff as an alternative source of animal protein feed that need to be examined is the prawn waste. Prawn waste meal enough potential to be used as fish feed with a crude protein content $45.29 \%$ and $17.59 \%$ crude fiber was alternative feed stuff for fish meal. The usage of prawn waste as a feed stuff should be through the handling and processing to further improve the nutrient value of waste. Prawn waste processing in this research consists of two ways, that is waste cooking prawn on the high pressure (100 kpa), and conducted fermentation by using probiotic. The existence of microorganisms activity during the fermentation process will cause changes of feed stuffs either through physically and chemicals. Probiotic is a microbe colony that is rich in celulolytic, lignolytic and proteolytic bacteria.

The aim of this research is to know the influence probiotic on the prawn waste cooked with high pressure to increase the protein content and to decrease the crude fiber content. Method as used in the research is experimental method. Experiment design that used at research is Completely Randomized Design with 4 treatments and replicates 5 times. To get the data is conducted procsimat analysis on the crude protein content and crude fibers from each experimental unit. That result data analyzed with the Analysis of Varian continued with Duncan's Multiple Range Test.

The results of research is known that dosaged probiotic at process of prawn waste cooked fermentation not different to crude protein contents of the waste cook fermented prawn. Crude fiber content of the waste cook fermented prawn using probiotik (P1, P2, P3) has decreased if compared with waste cooking fermented prawn without using probiotic $(\mathrm{PO})$.
\end{abstract}

Key words : probiotic, fermentation, prawn waste, protein, crude fibre

\section{Pendahuluan}

Pakan merupakan salah satu faktor penentu keberhasilan suatu usaha perikanan .Pakan yang berkualitas membutuhkan bahan baku yang berkualitas pula, yang sampai saat ini masih mengandalkan impor terutama tepung ikan dan bungkil kedelai. Usaha untuk mengurangi ketergantungan terhadap impor bahan baku pakan adalah mencari alternatif bahan baku yang kualitasnya cukup baik, murah, mudah didapat dan dapat menekan biaya produksi (Amri, 2007). Salah satu bahan pakan alternatif sebagai bahan pakan sumber protein hewani yang perlu diteliti adalah limbah udang. tepung limbah udang cukup potensial untuk dimanfaatkan sebagai bahan pakan ikan dengan kandungan protein kasar 45,29\% dan serat kasar 17,59\%. Menurut Mirwandhono dan Siregar (2004) dari kandungan protein yang cukup tinggi, limbah udang juga mengandung semua asam amino essensial terutama methionin. Kandungan serat kasar yang relatif tinggi menjadi faktor pembatas untuk tingkat penggunaan limbah udang (Poultry Indonesia, 2007). Penggunaan limbah udang sebagai bahan baku pakan harus melalui penanganan dan pengolahan lebih lanjut untuk meningkatkan nilai gizi dari limbah.

Pengolahan limbah udang yang mungkin dilakukan adalah fermentasi pada 
limbah udang yang telah dimasak dengan tekanan tinggi. Limbah udang yang akan difermentasi dimasak pada tekanan tinggi (100 kpa, kilo pressure cooker atmosfir) terlebih dahulu selama 45 menit dengan tujuan untuk melonggarkan ikatan hidrogen pada khitin sehingga protein yang terikat dapat terlepas dari ikatan hidrogen yang membentuk senyawa kompleks sehingga mudah dicerna (Zamora dkk., 1989 dalam Mirwandhono dan Siregar, 2004). Menurut Winarno dan Fardiaz (1980), fermentasi merupakan suatu proses yang terjadi melalui kerja enzim yang dihasilkan oleh mikroorganisme untuk mengubah bahan-bahan organik komplek menjadi molekul-molekul yang lebih sederhana. Probiotik merupakan koloni mikrobia yang kaya akan mikroba selulotik, lignolitik dan proteolitik. Mikroba selulotik menghasilkan enzim selulase, mikroba proteolitik menghasilkan enzim protease. Adanya enzim protease dan khitinase diharapkan dapat membantu memisahkan protein dengan khitin pada limbah udang (Ulfa, 2003). Nurhidayat (2002) menjelaskan bahwa enzim protease dapat digunakan untuk memisahkan nitrogen (N) pada ikatan khitin cangkang udang, sedangkan enzim selulase dapat memutuskan ikatan 1,4 glikosidik.

Tujuan dari penelitian ini adalah untuk mengetahui pengaruh probiotik pada pemasakan limbah udang dengan tekanan tinggi terhadap peningkatan kandungan protein kasar.

Untuk mengetahui pengaruh probiotik pada pemasakan limbah udang dengan tekanan tinggi terhadap penurunan kandungan serat kasar.

Sedangkan manfaat yang diharapkan yaitu memberikan informasi mengenai pengaruh probiotik pada pemasakan limbah udang dengan tekanan tinggi terhadap peningkatan kandungan protein kasar dan memberikan informasi mengenai pengaruh probiotik pada pemasakan limbah udang dengan tekanan tinggi terhadap penurunan kandungan serat kasar.

\section{Materi dan Metode Penelitian}

Penelitian ini dilaksanakan pada Mei 2008 di Laboratorium Makanan Ternak Fakultas Kedokteran Hewan, Universitas Airlangga.

Materi penelitian yang digunakan terdiri dari alat dan bahan penelitian. Peralatan yang digunakan dalam penelitian ini meliputi: kantong plastik $2 \mathrm{~kg}$, nampan plastik, gelas ukur, sprayer, panci presto, kompor, oven, seperangkat alat untuk analisis protein kasar yang terdiri dari: labu Kjeldhal $100 \mathrm{cc}$, pemanas labu Kjeldhal, spatula, timbangan elektrik Sartorius, gelas ukur, labu ukur $250 \mathrm{cc}$, erlenmeyer $250 \mathrm{cc}$, labu destilasi $500 \mathrm{cc}$, pendingin Lienbeigh, pipa bengkok, sumbat karet, pembakar bunsen dan kawat kasa. Seperangkat alat untuk analisis serat kasar: erlenmeyer $300 \mathrm{cc}$, erlenmeyer penghisap, corong Buchner, spatula, cawan porselen, gelas ukur, timbangan analitik, oven, penangas air dan kompresor. Bahan yang digunakan dalam penelitian ini adalah limbah udang, probiotik yang mengandung mikroba proteolitik: Bacillus dan Streptomyces, mikroba selulolitik: Cellulomonas dan Actinomyces, dan mikroba amilolitik: Bacillus dan Amilomyces dan air sumur masak dingin. Bahan kimia untuk analisis protein kasar yang terdiri dari: Tablet Kjeldhal, $\mathrm{H}_{2} \mathrm{SO}_{4}$ pekat, $\mathrm{NaOH} 40 \%$, Asam Borat, indikator Metil-Red, Brom Cresol Green, $\mathrm{H}_{2} \mathrm{SO}_{4} 0,01 \mathrm{~N}$, dan Aquadest. Bahan kimia untuk analisis serat kasar terdiri dari $\mathrm{H}_{2} \mathrm{SO}_{4}$ 0,3 $\mathrm{N}, \mathrm{NaOH} 1,5 \mathrm{~N}, \mathrm{HCl} 0,3 \mathrm{~N}$, Aceton dan $\mathrm{H}_{2} \mathrm{O}$ panas.

Penelitian ini bersifat eksperimental. Rancangan percobaan yang digunakan pada penelitian ini adalah Rancangan Acak Lengkap (RAL) dengan empat perlakuan dan 5 kali ulangan. Untuk mendapatkan data dilakukan analisis proksimat terhadap kandungan protein kasar dan serat kasar dari tiap unit percobaan. Data yang diperoleh diuji dengan Analisis Varian (Anava) dilanjutkan dengan Uji Jarak Berganda Duncan (Duncan's Multiple Range Test) (Kusriningrum, 2008).

Limbah udang yang diperoleh, dicuci bersih menggunakan air sumur yang telah dimasak kemudian dimasak pada tekanan tinggi selama 45 menit lalu dikeringkan menggunakan oven selama 24 jam dan dibagi secara acak menjadi 20 unit percobaan, masing-masing dengan berat 100 gram. Sebanyak 15 unit percobaan dicampur dengan probiotik sesuai dengan dosis yang telah ditetapkan. Selama proses fermentasi, kantong plastik dibiarkan terbuka. Limbah udang yang dimasak pada tekanan tinggi difermentasi dalam keadaan aerob dan lama fermentasi 7 hari. 


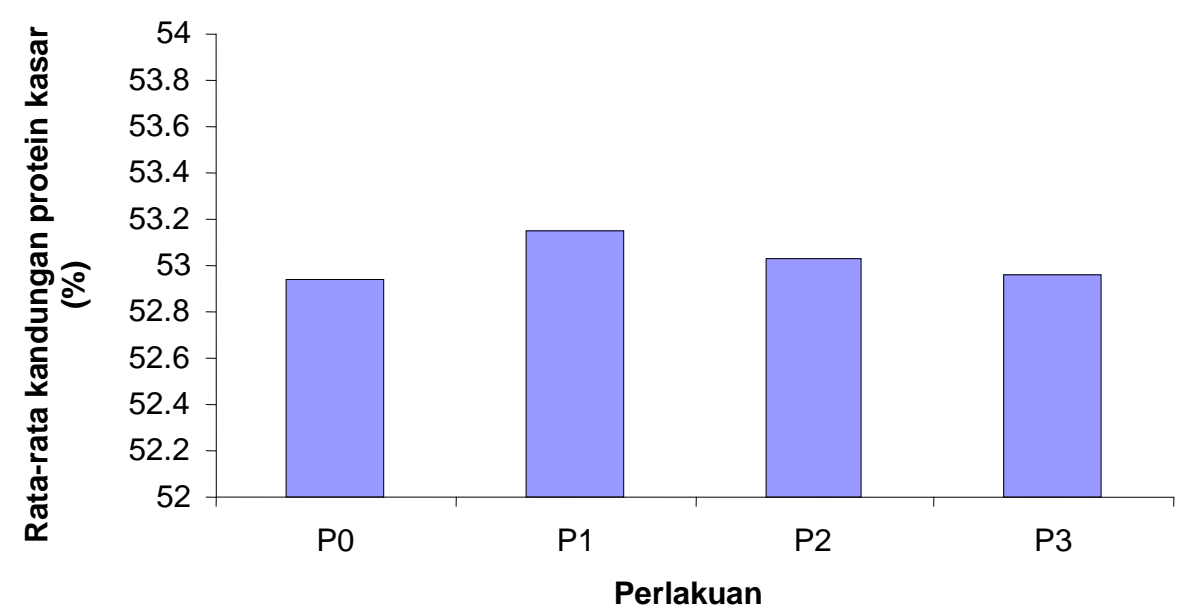

Gambar 1. Rata-rata kandungan protein kasar limbah udang masak terfermentasi

Setelah difermentasi selama 7 hari, limbah udang dikeringkan dibawah sinar matahari. Setelah kering, limbah udang digiling menjadi tepung kemudian dilakukan analisis proksimat terhadap semua unit percobaan untuk mengetahui kandungan protein kasar dan serat kasar dengan metode AOAC (Official Methods of Analysis, 1980).

Variabel yang digunakan dalam penilitian ini adalah variabel bebas yaitu dosis probiotik, variabel tergantung yaitu kandungan protein kasar (PK) dan serat kasar (SK) serta variabel terkendali yaitu tekanan pemasakan limbah udang dan waktu pemasakan.

Hasil penelitian akan dianalisis dengan menggunakan statistik Analisis Varian (Anava), bila terdapat perbedaan antar perlakuan dilanjutkan dengan uji jarak berganda Duncan (Duncan's Multiple Range Test) dengan derajat kepercayaan 95\% (Kusriningrum, 2008).

\section{Hasil dan Pembahasan}

Protein kasar

Rata-rata kandungan protein kasar limbah udang masak terfermentasi berdasarkan bahan kering dapat dilihat pada Tabel 2.

Tabel 1. Hasil rata-rata kandungan protein kasar limbah udang masak terfermentasi berdasarkan bahan kering

\begin{tabular}{|c|c|}
\hline $\begin{array}{c}\text { Dosis Probiotik } \\
(\%)\end{array}$ & $\begin{array}{c}\text { Rata-rata Kandungan } \\
\text { Protein Kasar }(\%)\end{array}$ \\
\hline P0 $(0 \%)$ & 52,9401 \\
\hline P1(3\%) & 53,1470 \\
\hline P2 (6\%) & 53,0256 \\
\hline P3(9\%) & 52,9561 \\
\hline
\end{tabular}

Berdasar data hasil analisis proksimat diketahui bahwa kandungan protein kasar tertinggi mencapai $53,1470 \%$ dan kandungan protein kasar terendah mencapai 52,9401\%. Berdasarkan hasil analisis statistik diketahui bahwa dosis probiotik pada proses fermentasi limbah udang masak tidak berbeda terhadap kandungan protein kasar limbah udang masak terfermentasi ( $>>0,05)$. Rata-rata kandungan protein kasar limbah udang masak terfermentasi disajikan pada Gambar 1.

\section{Serat Kasar}

Rata-rata kandungan serat kasar limbah udang masak terfermentasi berdasarkan bahan kering disajikan pada Tabel 3.

Tabel 2. Hasil rata-rata kandungan serat kasar limbah udang masak terfermentasi berdasarkan bahan kering

\begin{tabular}{|c|c|}
\hline Dosis Probiotik (\%) & $\begin{array}{c}\text { Rata-rata Kandungan } \\
\text { Serat Kasar }(\%)\end{array}$ \\
\hline P0 (0\%) & $17,2489^{\mathrm{a}}$ \\
\hline P1 $(3 \%)$ & $15,2043^{\mathrm{b}}$ \\
\hline P2 (6\%) & $15,0933^{\mathrm{b}}$ \\
\hline P3(9\%) & $15,1765^{\mathrm{b}}$ \\
\hline
\end{tabular}

Keterangan : superskrip pada kolom berbeda menunjukkan perbedaan $(\mathrm{p}<0,05)$

Berdasar data hasil analisis proksimat diketahui bahwa kandungan serat kasar tertinggi mencapai 17,2489\% dan kandungan serat kasar terendah mencapai 15,0933\%. Pada Tabel 3. menunjukkan dosis probiotik pada perlakuan P0, P1, P2 dan P3 berpengaruh nyata $(\mathrm{p}<0.05)$ terhadap kandungan serat kasar. Berdasarkan Uji Jarak Berganda Duncan's dapat diketahui bahwa kandungan serat kasar perlakuan P3, P2, P1 secara nyata $(\mathrm{p}<0.05)$ lebih rendah 


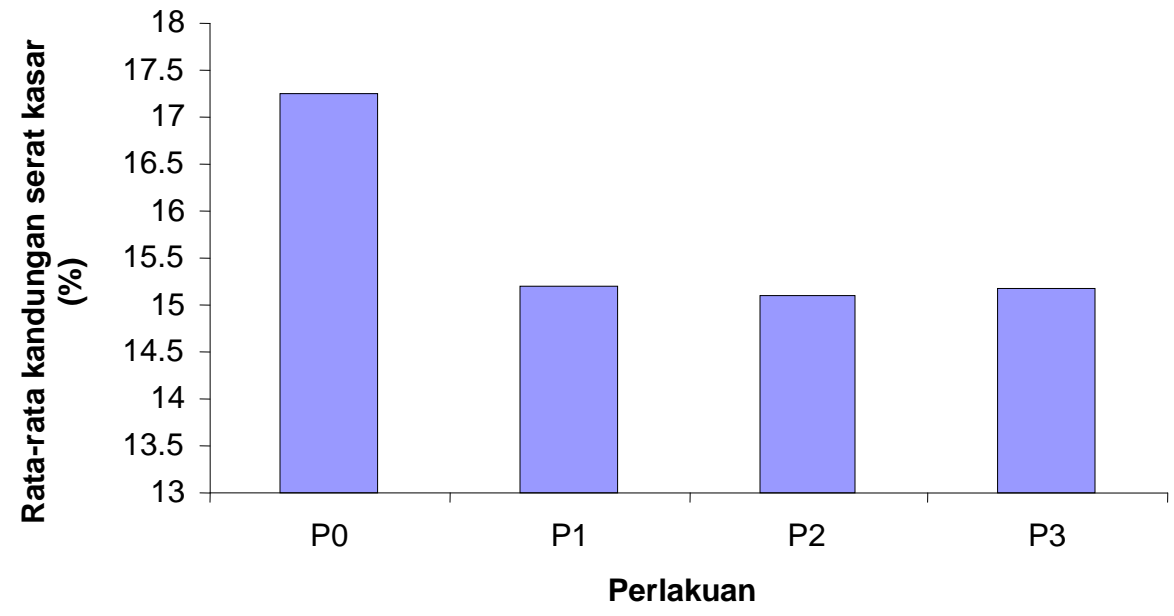

Gambar 2. Rata-rata kandungan serat kasar limbah udang masak terfermentasi

dibandingkan P0, sedangkan antara P3, P2 dan P1 tidak berbeda nyata $(\mathrm{p}>0.05)$.

Kandungan serat kasar limbah udang masak terfermentasi dengan menggunakan probiotik (P1, P2, P3) mengalami penurunan bila dibandingkan dengan limbah udang masak yang difermentasi tanpa menggunakan probiotik (P0). Rata-rata kandungan serat kasar limbah udang masak terfermentasi disajikan pada Gambar 6.

Hasil penelitian menunjukkan bahwa fermentasi limbah udang masak menggunakan probiotik selama tujuh hari belum dapat meningkatkan kandungan protein kasar. Hal ini mungkin disebabkan karena rendahnya nutrisi pada probiotik sehingga perkembangbiakan serta aktifitas mikroba menjadi terhambat. Menurut Lusiana (2005) persentase dosis probiotik yang tinggi tetapi jika kandungan nutrisinya rendah akan menyebabkan aktifitas mikroba dalam probiotik untuk tumbuh menjadi terhambat. Adanya sumber nutrisi yang memadai ditambah jumlah mikroorganisme yang tinggi menyebabkan aktifitas mikroorganisme juga tinggi (Wuryantoro, 2000).

Mikroba proteolitik yang terdapat dalam probiotik adalah Bacillus. Mikroba proteolitik dalam probiotik dapat mendegradasi limbah udang sehingga dapat meningkatkan kandungan protein kasar limbah udang. Diduga dalam penelitian ini jumlah populasi mikroba proteolitik sedikit sehingga jumlah bahan yang terfermentasi sedikit. Sedikitnya jumlah bahan yang terfermentasi menyebabkan kandungan protein kasar tidak dapat meningkat.
Hasil penelitian menunjukkan bahwa terjadi penurunan kandungan serat kasar pada fermentasi limbah udang masak menggunakan probiotik selama tujuh hari dari 17,2489\% (P0) menjadi $15,0933 \% \quad(\mathrm{P} 2)$. Menurunnya kandungan serat kasar limbah udang masak terfermentasi disebabkan karena inokulum yang digunakan pada penelitian ini mengandung mikroba Streptomyces. Mikroba Streptomyces dapat menghasilkan enzim khitinase yang dapat mendegradasi khitin. Hal ini sesuai dengan pernyataan Yurnaliza (2002), khitin dapat didegradasi oleh enzim khitinase yang dihasilkan oleh Streptomyces karena mikroba tersebut dapat memanfaatkan khitin sebagai sumber karbon dan nitrogen. Adanya enzim protease dan khitinase dapat membantu memisahkan protein dengan khitin pada limbah udang (Gooday, 1994 dalam Ulfa, 2003).

Streptomyces menghasilkan enzim khitinase yang terdiri dari endokhitinase dan $\beta$ 1,4-N asetilglukosamidase. Enzim ini dapat memecah khitin menjadi monomer $\mathrm{N}$ asetilglukosamin. $\quad$ Enzim $\quad \beta-1,4-\mathrm{N}$ asetilglukosamidase adalah enzim khitinolitik yang bekerja pada pemutusan diasetilkhitobiose dengan menghasilkan monomer Nasetilglukosamin (Yurnaliza, 2002).

Penambahan dosis probiotik menyebabkan populasi mikroba semakin banyak sehingga mampu mendegradasi komponen khitin lebih optimal. Aktivitas enzim hidrolisis serat kasar selalu berpengaruh pada daya cerna protein, karena molekul protein dapat terletak diantara molekul serat sehingga penguraian serat akan berpengaruh pada pelepasan molekul protein yang dapat 
menyebabkan meningkatnya daya cerna (Nurhidayat, 2002).

\section{Kesimpulan}

Penggunaan probiotik pada pengolahan limbah udang yang dimasak pada tekanan tinggi tidak dapat meningkatkan kandungan protein kasar.

Penggunaan probiotik $3 \%$ pada pengolahan limbah udang yang dimasak pada tekanan tinggi (100 kpa) dapat menurunkan kandungan serat kasar.

Selanjutnya, melakukan penelitian lebih lanjut menggunakan dosis probiotik lebih dari $9 \%$ atau penelitian lebih lanjut dengan pengolahan limbah yang lain, mikroba proteolitik maupun bakteri selulolitik yang lain pada fermentasi limbah udang masak serta pemberian tepung limbah udang terfermentasi pada hewan coba untuk mengetahui pengaruh terhadap konsumsi, pertumbuhan dan daya cerna.

Daftar Pustaka

Amri, M. 2007. Pengaruh Bungkil Inti Sawit Fermentasi Dalam Pakan Terhadap Pertumbuhan Ikan Mas (Cyprinus carpio L.). Fakultas Perikanan dan Ilmu Kelautan Universitas Bung Hatta. Padang. 71-76 hal.

AOAC. 1980. Official Methods of Analysis. $16^{\text {th }}$ Ed. Assosiation of Official Chemist. Washington DC.

Kusriningrum. 2008. Perancangan Percobaan. Airlangga University Press. Surabaya. 274 hal.

Lusiana, Y. 2005. Kandungan Protein Kasar dan Serat Kasar Jerami Padi Hasil Proses Fermentasi dengan Probiotik Alami dan Tetes. Skripsi. Fakultas Kedokteran Hewan. Universitas Airlangga. Surabaya. 56 hal.

Mirwandhono, E. dan Z. Siregar. 2004. Pemanfaatan Hidrolisat Tepung Kepala Udang dan Limbah Kelapa Sawit Yang Difermentasi Dengan Aspergillus niger, Rizhopus oligosporus dan Thricoderma viridae Dalam Ransum Ayam Pedaging. Fakultas Pertanian Universitas Sumatera Utara. Sumatera Utara. 12 hal.

Nurhidayat. 2002. Pengaruh Waktu Inkubasi Pada Biodegradasi Aspergillus niger Terhadap Kandungan Zat Makanan Kecernaan Protein dan Energi Metabolis Campuran Ampas Garut dan Limbah Udang. Skripsi. Fakultas Peternakan. Universitas Brawijaya. Malang. 57 hal.
Poultry Indonesia. 2007. Limbah Udang Pengganti Tepung Ikan. 1 hal http://www.poultryindonesia.com. 5 Desember 2007

Ulfa, U. 2003. Penggunaan Campuran Dedak Padi dan Limbah Udang Terfermentasi pada Puyuh Petelur (Cortunix-cortunix japonica). Skripsi. Jurusan Nutrisi dan Makanan Ternak. Fakultas Peternakan. Universitas Brawijaya. Malang.

Winarno, F. G. dan S. Fardiaz. 1980. Biofermentasi dan Biosintesa Protein. Angkasa. Bandung.

Wuryantoro, S. 2000. Kandungan Protein Kasar dan Serat Kasar Hay Padi Teramonisasi Yang Difermentasi Dengan Cairan Rumen. Skripsi. Fakultas Kedokteran Hewan. Universitas Airlangga. Surabaya. 42 hal.

Yurnaliza. 2002. Senyawa Khitin Dan Kajian Aktivitas Enzim Mikrobial Pendegradasinya. Fakultas Matematika Dan Ilmu Pengetahuan Alam. Universitas Sumatara Utara. Sumatra Utara. 12 hal. 